\title{
37. GEOLOGICAL RESULTS OF LEG 16: THE CENTRAL EQUATORIAL PACIFIC WEST OF THE EAST PACIFIC RISE
}

\author{
Tjeerd H. van Andel and G. Ross Heath, School of Oceanography, Oregon State \\ University, Corvallis, Oregon
}

\begin{abstract}
The combined drilling results of Legs 8,9 , and 16 west of the East Pacific Rise have helped clarify the tectonic and depositional history of the eastern equatorial Pacific Ocean. Basement ages inferred from the overlying sediments yield spreading rates of 6-9 $\mathrm{cm} / \mathrm{yr}$ for the period $20-80$ million years B.P. The zone of thick biogenous sediments, now located near the equator, is offset further and further north in successively older epochs of the Cenozoic. The Eocene position is near $20^{\circ} \mathrm{N}$. This migration can best be explained by a northward movement of the Pacific plate. A change in the relative rate of southward movement of the equatorial sedimentation axis around 30 million years B.P. may reflect a change in the direction of plate movement. The sedimentary facies indicate that the equatorial zone of biological productivity was widest and the productivity most intense or the rate of calcite dissolution was least intense during the middle Cenozoic.

From the Oligocene to the present, the zone of biogenous sediments has gradually narrowed and the associated gross sedimentation rate has steadily decreased. Between the Eocene and the Oligocene a major lithologic boundary separates a dominantly siliceous from a dominantly calcareous series of deposits. This may reflect an abrupt change in the depth of the calcite compensation level, perhaps accentuated by changes in the pattern of biologic fixation of calcite in surface ocean waters.
\end{abstract}

\section{INTRODUCTION}

The principal objectives of the Deep Sea Drilling Project, as stated in the original proposal made by JOIDES to the National Science Foundation, were: a) to examine the manner in which the ocean basins and their principal tectonic features have attained their present configuration, and b) to study the depositional history of the oceans, the history of their current systems and water masses, and the evolution of oceanic life during the Cenozoic and Mesozoic. One of the strategies devised to reach this end was a series of traverses in the eastern and central equatorial Pacific, both north-south and east-west, that were drilled on Legs 5, $7,8,9,16$, and 17 to provide a regional grid of approximately twenty-five sites between the crest of the East Pacific Rise and the Line Islands and between $25^{\circ} \mathrm{N}$ and $12^{\circ} \mathrm{S}$ latitude. This grid forms the basis for a tectonic study of this part of the Pacific. More importantly, it also provides excellent data for a study of the behavior of the equatorial Pacific circulation and its associated life during the Cenozoic. The time span covered by the drilling results extends into the late Cretaceous in the western part of the area (DSDP 163,Campanian;DSDP 164, Aptian-Barremian), but most of the sediments present in the region were laid down during the Cenozoic.
The objectives of the Leg 16 portion of this regional drilling program were the following:

1) To complete the regional grid of drill sites in the equatorial Pacific.

2) To complete a traverse at $140^{\circ} \mathrm{W}$ (started on Legs 5 and 8 ) designed to study the history of the equatorial belt of biogenous sediments.

3) To obtain additional material for a comprehensive Cenozoic and Mesozoic biostratigraphic zonation of the equatorial Pacific.

4) To determine, with new coring techniques, basement ages between the crest of the East Pacific Rise and the Line Islands in the region where magnetic anomalies are difficult to decipher because of the low magnetic latitude.

5) To further define the extent, nature, and genesis of the metal-enriched sediments immediately overlying basement which were discovered during earlier drilling on the west flank of the East Pacific Rise (Legs 5 and 9).

The introduction of new drill bits capable of penetrating the early Cenozoic chert sequences that had impeded penetration to basement on previous legs greatly contributed to achievement of these objectives.

This chapter summarizes some of the general geological results of the cruise as they bear on the objectives stated above. For this purpose it also draws heavily on the results 
of previous legs, in particular Leg 5 (McManus, Burns et al., 1970), Leg 8 (Tracey, Sutton et al., 1971a) and Leg 9 (Hays et al., 1972a). A variety of subjects has been summarized in other chapters of this report and will not be reviewed in detail here. The physical properties of the sediments are discussed in Chapter 13; a summary of the studies of the basal metal-bearing sediments is presented in Chapter 18; Chapter 20 contains a discussion of the cherts cored on this leg; and the petrography and geochemistry of the basalts are given in Chapter 22, while their velocities and magnetic properties are discussed in Chapters 23 and 24. Potassium-argon dating of DSDP 163 basalt is discussed in Chapter 25. The biostratigraphy of the sediments west of the crest of the East Pacific Rise is summarized in Chapter 36.

\section{TECTONIC EVOLUTION}

The primary contribution of the Deep Sea Drilling Project to knowledge of the tectonic history of the ocean basins rests on the determination of the age of the oceanic basement in drill holes. Other possible approaches, such as use of the history of uplift and subsidence inferred from sedimentary facies, have not yet been explored on a global scale.

\section{Establishing the Age of the Oceanic Crust}

The age of the oceanic basement can be determined in two ways: by direct isotopic age dating of the basalt and by extrapolation from a biostratigraphic age assigned to the sediment immediately overlying basement. The first method has rarely been used, as oceanic basalts are difficult to date because of low potassium contents, argon retention problems, and the large influence of even minor degrees of alteration. The few attempts have yielded results that are sometimes at variance with the ages obtained by extrapolation from overlying sediments (MacDougall, 1971; Dymond, this volume, Chapter 25). Although some authors have claimed that these discrepancies constitute a major weakness in the body of data defining the age of the oceanic crust (for example, Meyerhoff and Meyerhoff, $1972 \mathrm{a}$ and b), the difficulties associated with absolute age determinations of oceanic basalts are so large and the consistency of the biostratigraphically based ages is so good that such a sweeping condemnation does not seem warranted.

Nevertheless, there is reason for caution in the use of biostratigraphic ages in lieu of absolute basement ages (van Andel, 1972). Baked sediment-basalt contacts have been observed in a number of cases; for example, in all holes of Leg 9 (Hays et al., 1972b; Winterer et al., 1971), thus demonstrating that a shallow penetration of igneous rock does not guarantee that the primary oceanic crust has been reached. The fact that some of these sills did not exhibit clearly identifiable baked contacts increases the difficulty of recognizing them as such. Although Hays et al. (1972b) argue rather persuasively that the intrusion of younger sills producing baked contacts in Leg 9 holes must have taken place at the original sediment-basalt interface without destroying a significant portion of the sedimentary record, the existence of basalt sills at shallow depths in the sedimentary sequence urges caution in the use of indirect basement ages.
Problems of a different kind result from the sometimes inadequate knowledge of the precise geological configuration of the drill site. Many drill sites are located in areas where the presence of an acoustically opaque chert horizon prevents examination of the basement topography by seismic reflection. Where this is the case, it is impossible to determine whether the hole was placed in the right position to sample the oldest sediments in the area. Several configurations where this would not be the case are possible, including drilling in an area of high but concealed basement relief with significant downslope displacement of sediments, a situation common on mid-oceanic ridge crests (van Andel and Komar, 1969), or in areas of near-bottom transport of sediment. Some hypothetical cases (Figure 1) illustrate the false results that could be obtained. In addition, widespread sea-floor erosion, now known to be common on mid-ocean ridges and even on the abyssal floor in the central equatorial Pacific, threatens the assumption that no significant time interval separates the cooling of the primary basalt and the deposition of the first sediments.

Thus, our confidence in basement ages obtained by extrapolation from the overlying sediment is largely a function of the degree to which the age pattern so obtained conforms to a geologically meaningful tectonic configuration. Clearly, this may lead to a reversal of fact and hypothesis. This is illustrated by Winterer et al. (1971), who present as one possible explanation of the pattern of basement ages obtained on Leg 17, the presence of young flood basalts of regional extent, a hypothesis necessitated mainly by the lack of agreement between the observed basement ages and postulated sea floor spreading patterns.

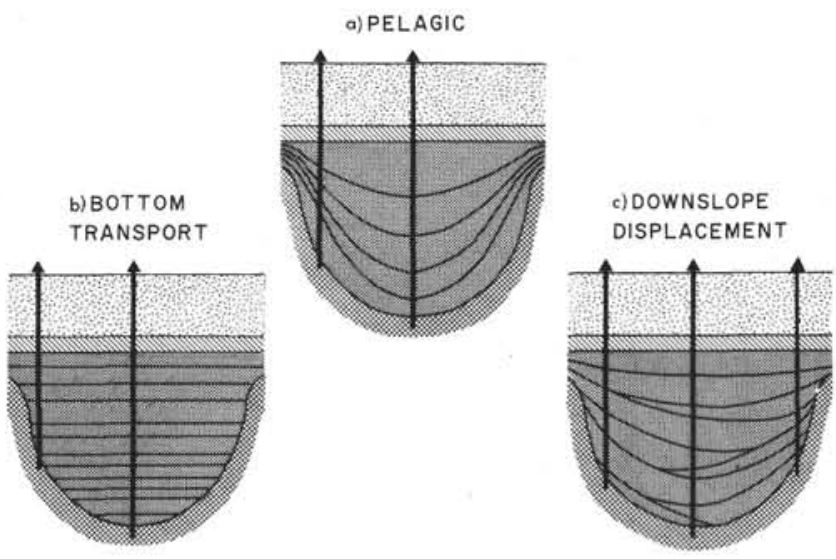

Figure 1. Diagram of some possible relations between the oldest sediment cored in a borehole and the oldest sediment actually present in an area for conditions of a) pelagic particle-by-particle deposition, b) deposition by bottom currents, c) slumping and downslope displacement of sediments. The diagonally hachured layer in the upper part of each sedimentary section is an acoustically opaque zone which prevents the examination of basement configuration by seismic profiler.

\section{Crustal Accretion West of the East Pacific Rise}

The evolution of the Pacific plate postulated by Morgan (1968) and LePichon (1968) has recently been shown to be too simple (McKenzie and Sclater, 1969; Sclater et al., 
1971; Herron, 1972). The present evidence indicates that in the equatorial region the zone of divergence between the Pacific and Cocos plates was located west of the present East Pacific Rise crest for the period prior to approximately 10 million years B.P. The most probable location for the old boundary is the Mathematicians Ridge and its southward extensions near $112^{\circ} \mathrm{W}$. In a comprehensive paper based on bathymetric and magnetic data, Herron (1972) has detailed the location and history of this old plate boundary in the equatorial and South Pacific. Between $19^{\circ} \mathrm{N}$ and $15^{\circ} \mathrm{N}$, the extinct boundary coincides with the Mathematicians Ridge, and between $10^{\circ} \mathrm{N}$ and $7^{\circ} \mathrm{N}$, with the Clipperton Ridge (Figure 2). Another segment is located between $7^{\circ} \mathrm{N}$ and the equator near $115^{\circ} \mathrm{W}$. Between $15^{\circ} \mathrm{N}$ and $10^{\circ} \mathrm{N}$, the position of the extinct axis is uncertain (Anderson and Davis, 1972), and south of the equator to $5^{\circ} \mathrm{S}$, its presence has not yet been demonstrated. South of $5^{\circ} \mathrm{S}$, the extinct plate boundary lies east of the East Pacific Rise. In general, because of the low magnetic latitude, the details of the spreading history between $15^{\circ} \mathrm{N}$ and $15^{\circ} \mathrm{S}$ are still open to question.

Basement ages west of the East Pacific Rise have been obtained at five Leg 16 drill sites. These are all located west of the Mathematicians Ridge between the Clarion and Clipperton fracture zones. In addition, one Leg 9 site (DSDP 78) is located in the same block; three Leg 9 sites (DSDP 77, DSDP 79, and DSDP 80) are located west of the extinct plate boundary in the block south of the Clipperton, and one (DSDP 81) in the block east of the axis. Basement ages based on the biostratigraphic age of the overlying sediment are given in Table 1 and Chapter 36; justification for the Leg 16 ages is presented in the appropriate site chapters, while the Leg 9 data, with very minor corrections, were taken from Hays et al. (1972a). Error limits involve uncertainties regarding the precise position of the oldest sediment within its stratigraphic zone, uncertainties in the absolute ages of zone boundaries (Berggren, 1969, Moore, 1972), and the position in the hole of the oldest dated sediment (van Andel, 1972). Since all sites lie on crust generated at the extinct plate boundary, only the distance to this boundary has been given.

Between the Clarion and Clipperton fracture zones, we have assumed another, unnamed fracture zone. This fracture zone was predicted by Sclater et al. (1971). It can be traced across the Line Islands ridge (Winterer, E.L., personal communication) and is required by the ages and positions of drill sites on both sides. Herron (1972) has assumed a fracture zone in approximately the same position. In Figure 3 the basement age determinations have been plotted against distance from the extinct plate boundary in three groups: between the Clarion and the unnamed fracture zone ("south of Clarion"), between the unnamed and the Clipperton fracture zones ("north of Clipperton"), and in the block south of the Clipperton Fracture Zone.

The age-distance plots permit several inferences. Discrepancies exist between the age-distance plots for magnetic anomalies taken from Herron (1972) and those for basement ages, except for the block south of the Clipperton. In the northern two blocks, the magnetic anomalies as identified by Herron give higher ages for corresponding distances from the spreading axis than the basement ages determined at drill sites and consequently yield significantly lower spreading rates. This discrepancy is on the order of $20 \mathrm{~m} . \mathrm{y}$. at a distance of $3000 \mathrm{~km}$ from the Mathematicians Ridge. Two explanations are possible: a) the magnetic anomalies have been misidentified, a distinct possibility in this region of very low magnetic amplitudes; and b) young sills intruded at some later time have destroyed a significant portion of the sedimentary record so that true basement was not reached. The magnetic profile obtained by R. V. Glomar Challenger is of no assistance because the amplitude of the anomalies over most of the track is so close to the diurnal variation that reliable identifications are impossible. As regards the second alternative it would, as Hays et al. $(1972 \mathrm{~b})$ point out, be remarkably fortuitous if sills had been intruded at all locations at precisely such levels that a linear relationship between age and distance was preserved. This argument is compelling for the groups of sites on either side of the Clipperton Fracture Zone but obviously cannot be invoked for the two sites south of the Clarion Fracture Zone. However, except for slight indications at DSDP 78, there is no evidence for intrusive contacts in any of the drill sites north of the Clipperton Fracture Zone, and Hays et al. (1972b) have cited various arguments that render it unlikely that a significant portion of the sedimentary record of the Leg 9 sites was destroyed by late intrusions. Finally, the long basalt core obtained at Site DSDP 163 consists of several superimposed thin flows, each bounded by glassy crusts. Petrologic arguments speak against an origin as a series of sills (Yeats et al., this volume, Chapter 22; Dymond, this volume, Chapter 25). Thus we consider it reasonable to accept the ages listed in Table 1 as true basement ages.

TABLE 1

Basement Ages of DSDP Sites in the Central Eastern Pacific

\begin{tabular}{|c|c|c|}
\hline Site & $\begin{array}{l}\text { Distance to } \\
\text { Extinct Axis } \\
(\mathrm{km})\end{array}$ & $\begin{array}{c}\text { Age }^{\mathrm{a}} \\
\left(\mathrm{yrs} \times 10^{6}\right)\end{array}$ \\
\hline \multicolumn{3}{|c|}{ South of Clarion F.Z. } \\
\hline $\begin{array}{l}163 \\
162\end{array}$ & $\begin{array}{l}4,210 \\
3,080\end{array}$ & $\begin{array}{l}78^{b} \pm 4.0 \\
49-2 /+5.0\end{array}$ \\
\hline \multicolumn{3}{|c|}{ North of Clipperton F.Z. } \\
\hline $\begin{array}{r}161 \\
160 \\
78 \\
159\end{array}$ & $\begin{array}{l}3,335 \\
2,370 \\
1,950 \\
1,330\end{array}$ & $\begin{array}{l}45-2 /+5.5 \\
34-1 /+1.5 \\
35 \pm 1 \\
23-1 /+6.0\end{array}$ \\
\hline \multicolumn{3}{|c|}{ South of Clipperton F.Z. } \\
\hline $\begin{array}{l}77 \\
80 \\
79 \\
81\end{array}$ & $\begin{array}{r}1,980 \\
690 \\
650 \\
170\end{array}$ & $\begin{array}{l}40-1 /+3 \\
21-1 /+2.5 \\
21 \pm 1 \\
15 \pm 1\end{array}$ \\
\hline
\end{tabular}




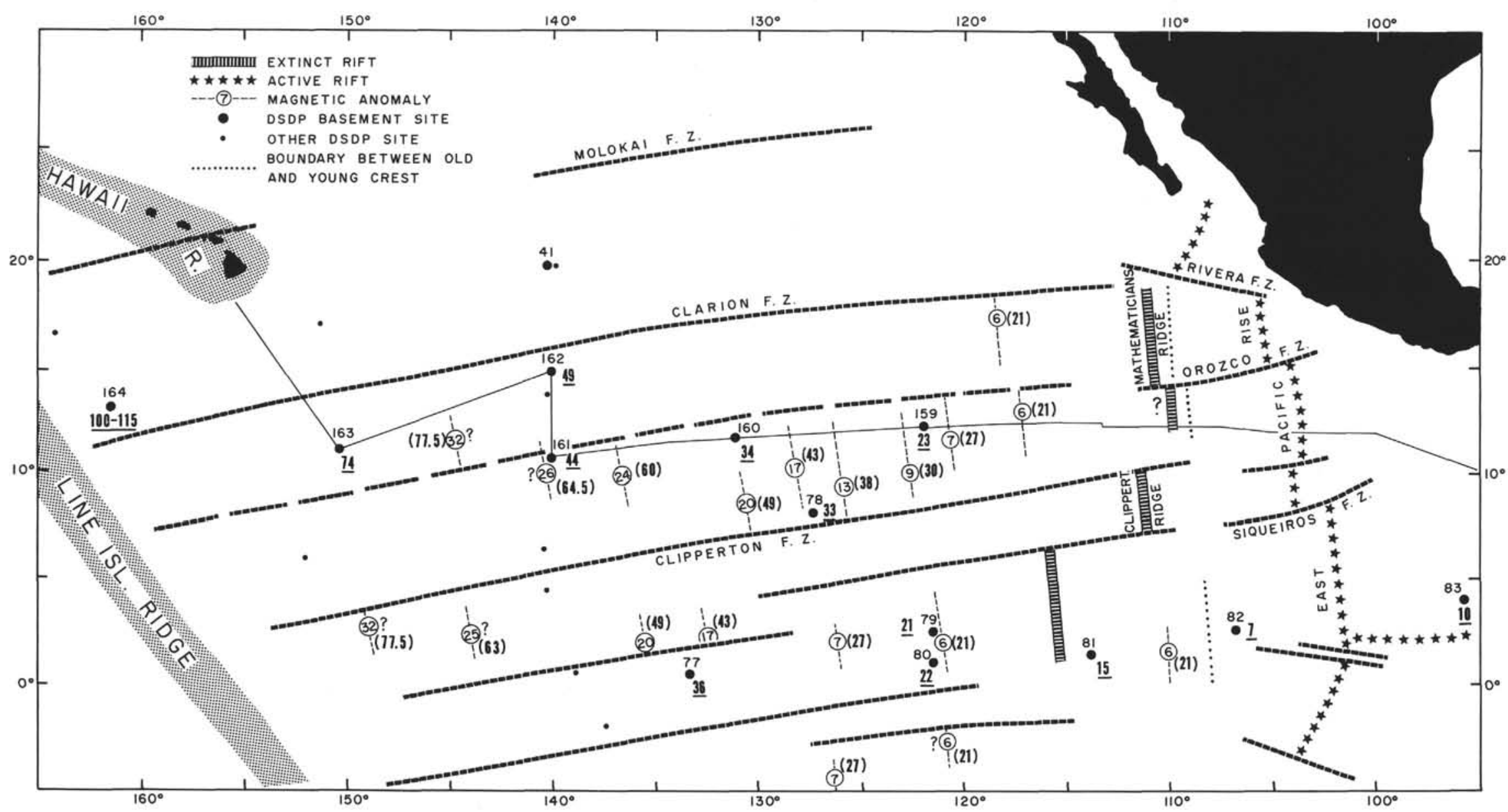

Figure 2. Tectonic sketch of the eastern central equatorial Pacific, showing location of drill sites (black dots) and magnetic anomaly patterns (lines identified with circled numbers). Positions of fracture zones (heavy dashed lines), extinct spreading centers (shaded bands), and the crest of the East Pacific Rise (stars) from Chase et al. (1970), Sclater et al. (1971), and Herron (1972). Magnetic anomalies after Herron (1972); ages (in brackets) according to Heirtzler et al. (1968) time scale. Basement ages of drill sites underlined; sites without basement penetration shown as small unnumbered dots. Heavy dotted lines indicate the boundary between crust generated from extinct spreading centers and crust formed at the East Pacific Rise. Thin line is the Leg 16 track of $R$. V. Glomar Challenger. Postulated fracture zone shown by interrupted dashed lines. 


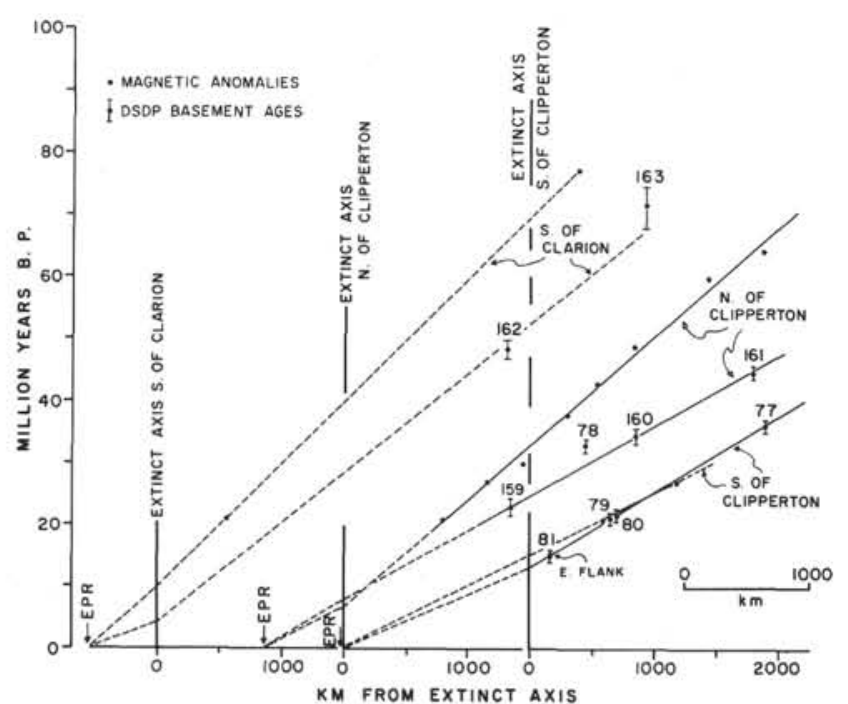

Figure 3. Crustal ages plotted against distance from extinct plate boundary. Basement ages based on drilling are shown with numbered error bars; regression lines fitted by eye. Black dots are positions and ages of magnetic anomalies after Herron (1972). Data are plotted separately for three blocks: Clarion to unnamed fracture zone; unnamed fracture zone to Clipperton; south of Clipperton. Origin in each case is location of extinct spreading axis; position of East Pacific Rise shown with arrow to the left of each origin.

The age-distance plots of basement ages north and south of the Clipperton Fracture Zone are quite linear. Thus, when extrapolated back to the position of the Mathematicians Ridge, they permit the determination of the approximate time that spreading ceased on this rift. This time varies systematically from about $3-4$ m.y. just south of the Clarion, to $7 \mathrm{~m} . \mathrm{y}$. north of the Clipperton, and approximately $14 \mathrm{~m} . \mathrm{y}$. near the equator, suggesting a stepwise or gradual shift to the present East Pacific Rise over a period of $10 \mathrm{~m} . \mathrm{y}$. This long time is worth noting in view of the often implied instantaneous nature of reorientations of the patterns of plate movement.

The spreading rates obtained from basement ages vary from nearly $6 \mathrm{~cm} / \mathrm{yr}$ to $9 \mathrm{~cm} / \mathrm{yr}$ (Table 2). They do not show the southward increase expected from the location of the rotational pole for the Pacific and Cocos plates near $80^{\circ} \mathrm{N}$ and $110^{\circ} \mathrm{W}$ (Herron, 1972), but in view of the large errors in age, the difference between blocks is not significant.

At Site DSDP 163, there is a large difference between the biostratigraphic age of the oldest sediment and the more than 20 m.y. younger radiometric age (Dymond, this volume, Chapter 25). The nature of the basalt appears to rule out a late intrusive origin and the uncertainty of the biostratigraphic age is far smaller than 20 m.y. Failure of one of the basic assumptions of radiometric dating (either loss of argon or uptake of potassium by finely crystalline intergranular smectites) seems the most probable explanation of the discrepancy.
TABLE 2

Spreading Rates in the Eastern Pacific, 10-70 Million Years B.P.

\begin{tabular}{l|c|c|c}
\hline & & \multicolumn{2}{|c}{$\begin{array}{c}\text { Spreading Rate (cm/yr) } \\
\text { Based On }\end{array}$} \\
\cline { 3 - 4 } \multicolumn{1}{c|}{ Block } & $\begin{array}{c}\text { Interval } \\
\text { (m.y.) }\end{array}$ & $\begin{array}{c}\text { Magnetic } \\
\text { Anomalies }\end{array}$ & $\begin{array}{c}\text { Basement } \\
\text { Ages }\end{array}$ \\
\hline Sedna to Surveyor & $20-75$ & 3.6 & \\
Surveyor to Mendocino F.Z. & $20-75$ & 3.9 & \\
Pioneer to Murray F.Z. & $20-75$ & 4.4 & \\
Murray to Molokai F.Z. & $20-75$ & 4.7 & \\
Molokai to Clarion F.Z. & $20-75$ & 4.9 & abt 6.8 \\
Clarion to unnamed F.Z. & $10-75$ & & abt 9.0 \\
Unnamed to Clipperton F.Z. & $10-75$ & & 7.0 \\
South of Clipperton F.Z. & $10-75$ & $9.4^{\mathrm{b}}$ & \multicolumn{2}{|c}{}
\end{tabular}

Spreading rates between Sedna and Clarion fracture zones have been calculated from Hayes and Pitman (1970); errors are large because of map scale.

a Based on Heirtzler et al. (1968) geomagnetic polarity time scale.

${ }^{b}$ Based on magnetic anomaly interpretation by Herron (1972).

\section{DEPOSITIONAL HISTORY}

On Legs $5,7,8,9,16$, and 17 a total of twenty-four sites were drilled in the central equatorial Pacific between the East Pacific Rise and the Line Islands ridge and between $25^{\circ} \mathrm{N}$ and $12^{\circ} \mathrm{S}$ latitude. Together, these sites provide material for a study of the stratigraphic and lithologic evolution of the region during the latest Mesozoic and the Cenozoic. Considerable work is still required, however, to coordinate the biostratigraphy of sites drilled on different legs, and additional sedimentary petrographic studies are needed to better define the sedimentary sequences before a comprehensive study of the sedimentary history of the region can be prepared. This work is beyond the scope of the present report, but a preliminary discussion of regional aspects of sedimentation during the Cenozoic can now be presented.

\section{Lithologic Types and Formations}

Two sediment types dominate the sequences at Sites DSDP 159 to DSDP 163, and at all other sites in the central equatorial Pacific as well: nannofossil ooze and its consolidated equivalents, chalk ooze and chalk, and a non-calcareous suite ranging from radiolarian ooze to brown ("red") clay. Subordinate types are chert, associated with either of the two main lithotypes; volcanic ash, which is generally present only in small amounts; and brown, ferruginous clay enriched in transition metals, which occurs at several sites near the basalt-sediment interface (Cronan, this volume, Chapter 18). Hemipelagic deposits of continental origin are rare west of the East Pacific Rise crest.

The two principal lithotypes can be subdivided into several lithologic units. Although such units, which are described in the site chapters, were independently established for each locality, they can to some extent be generalized and correlated over the entire equatorial region and can be compared to the lithologic units defined by earlier legs. 
Tracey, Sutton et al. (1971) defined three formations on the basis of these lithologic units and their interrelationships. From oldest to youngest, these are the Line Islands, Marquesas, and Clipperton formations. Hays et al. (1972b) recognized the same formations in Leg 9 boreholes, distinguished two separate members of the Clipperton Formation, and defined one additional formation, the San Blas Formation, which consists of green and grayish clays of continental origin found in the easternmost of the Leg 9 drill sites. The same formations, with the exception of the San Blas, can be identified in Holes DSDP 159 to DSDP 163 (Figure 4; Table 3). West of a point between DSDP 160 and DSDP 161, the Line Islands Formation forms the lower part of the sequence. It is, at most sites, underlain by an unnamed unit consisting of ferruginous, metal-bearing brown clay which usually rests immediately on basalt and extends discontinuously as far east as DSDP 159 (see Chapter 18, this volume). This clay has also been found in several holes of Leg 5 on the west flank of the East Pacific Rise and in holes of Leg 9. In the eastern part of the equatorial region, the Marquesas Formation, a prominent, purely calcareous unit of locally great thickness, overlies the Line Islands Formation; its westernmost occurrence is at Site DSDP 162. Farther west, the Line Islands Formation is overlain directly by another siliceous unit, the Clipperton Formation, which to the east overlies the Marquesas Formation. At the western sites, the distinction between the Clipperton and Line Islands formations is not well defined because the formations comprise essentially the same lithologic units and because the cyclic bedding which is characteristic for the Clipperton farther east is not well developed. The Clipperton becomes progressively less calcareous toward the west.
Regional Sediment Distribution and Depositional History

The drill sites of Legs 8,9 , and 16 are located in the equatorial zone of high biological productivity. The divergence of surface waters at the equator and a very shallow thermocline at the northern edge of the Equatorial Countercurrent bring nutrient-rich deep water into the near-surface habitat of phytoplankton and produce a latitudinal band with a high standing crop of plankton. As a result, the pelagic sediments beneath this region are composed primarily of the calcareous and siliceous remains of planktonic microorganisms. Thus, near the equator, highly calcareous sediment forms a latitudinal band (Figure 5) which grades northward and southward into siliceous radiolarian oozes and finally into the sparsely fossiliferous or barren red and brown clays of the nonproductive gyres of the central North and South Pacific waters. Coinciding with the change in composition is a large decrease in sedimentation rate from more than one centimeter per thousand years near the equator to less than one millimeter per thousand years in the red clay areas. These gradients away from the equator correspond to large changes in the total thickness of the acoustically mappable sediment cover. The equatorial sediments form a lens with its long axis approximately parallel to and near the equator (Figure 6; Ewing et al., 1968).

Another important factor affecting the composition of sediments and their accumulation rates is solution of calcium carbonate at the sea floor. This process probably begins where the ocean passes from super- to undersaturation (about $500-800 \mathrm{~m}$ in this region), but its effect on the sediments is difficult to recognize above the lysocline (approximately $3800 \mathrm{~m}$ in this region; Berger, 1971), where the rate of solution apparently increases abruptly. At the

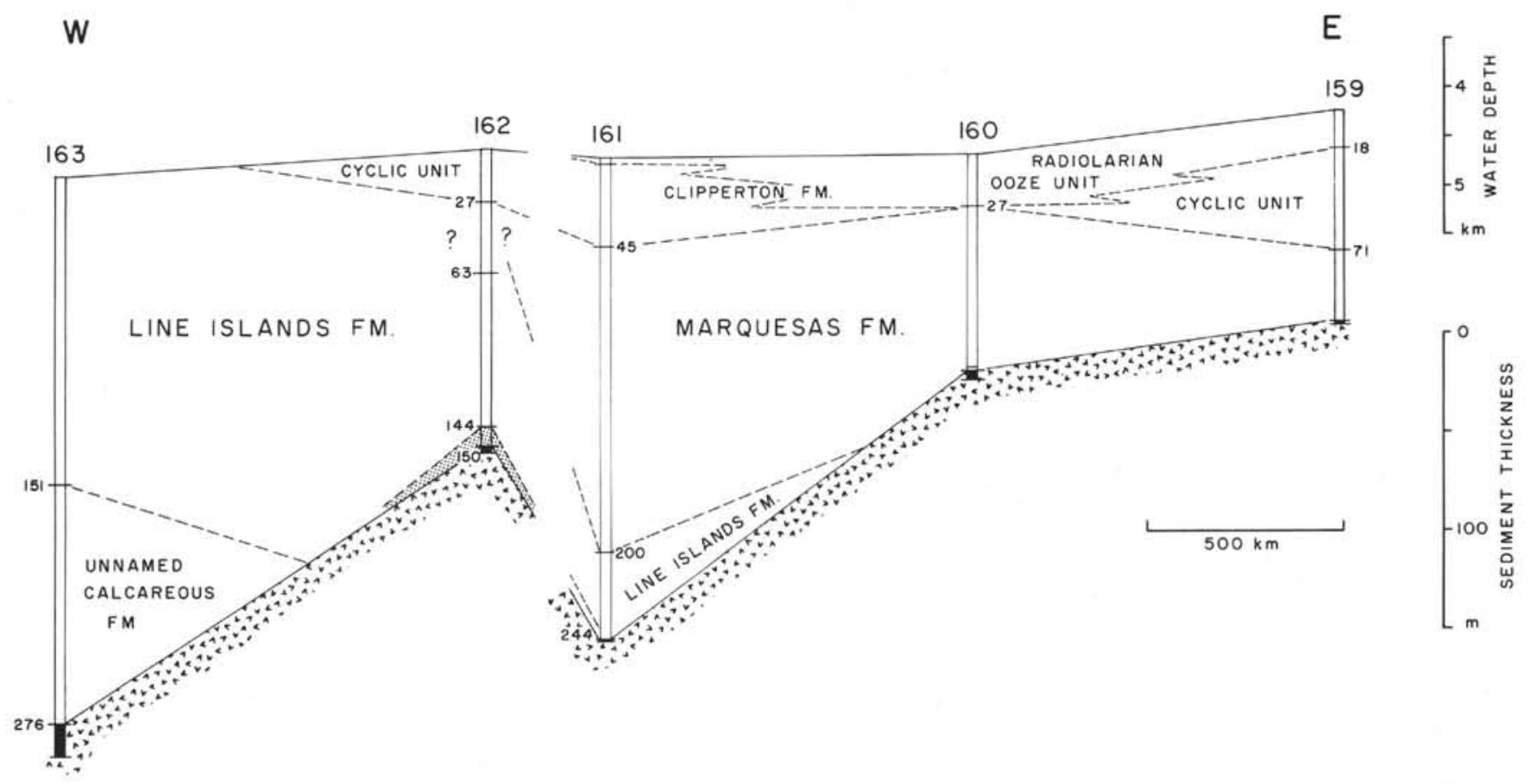

Figure 4. Pelagic sedimentary formations in boreholes of Leg 16 on west flank of East Pacific Rise. Formation names after Tracey, Sutton et al. (1971b). Profile is approximately parallel to the Clarion Fracture Zone; horizontal scale approximate. 


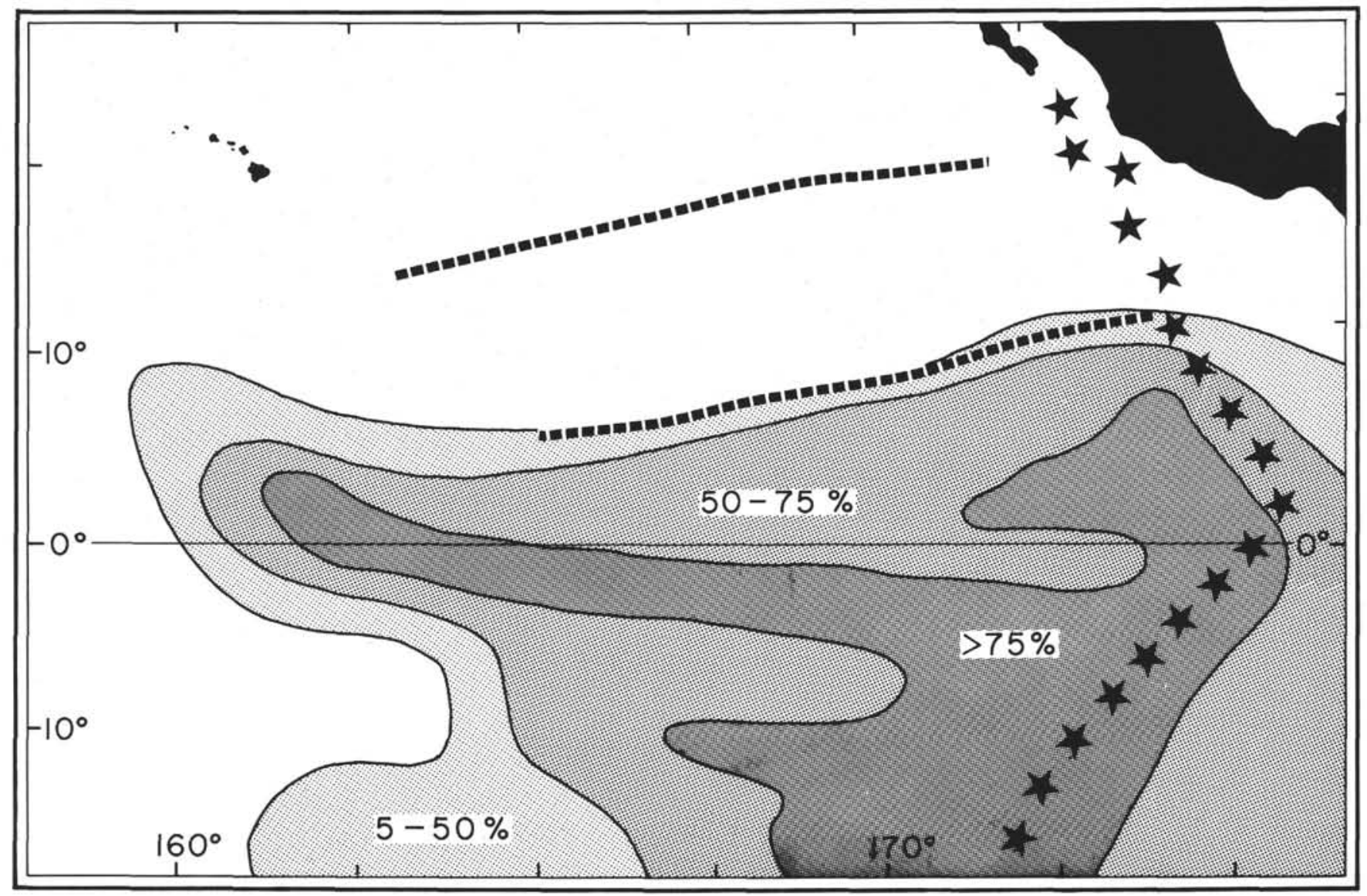

Figure 5. Distribution of calcium carbonate in surface sediments of the central equatorial Pacific (after Bramlette, 1961).

calcite compensation level, near $4700-4800$ meters in the central Pacific, the rate of dissolution equals that of supply, so that deposits at greater depths are free of calcium carbonate (Bramlette, 1961). This pattern of dissolution results in a reduction of sedimentation rate with increasing depth. The rate appears to drop fairly linearly between the lysocline and compensation level (Heath and Culberson, 1970), although the exact form of the rate curve is still uncertain (Berger, 1971). Very high surface productivity partially overrides the effect of dissolution on sedimentation rates, but in general the nature of deep-water sediments on the central Pacific floor is controlled by their elevation relative to the calcite compensation level and the lysocline (Figure 5).

The migration of the ocean floor away from its zone of formation at the crest of the East Pacific Rise or Mathematicians Ridge to abyssal depths gradually changes the level of deposition relative to the calcite compensation level and lysocline. Sediments rich in calcareous components and showing minor solution effects are gradually succeeded by more and more siliceous deposits as the crust gets older, leading to a sequence from rapidly deposited foraminiferal nannofossil oozes through nannofossil and radiolarian oozes to slowly accumulating brown clays. A theoretical model of the resulting sedimentary sequence on the flank of an equatorial mid-ocean ridge and of the relation between lithologic boundaries and time lines is shown in Figure 7.
For the last 70 m.y., spreading in the central equatorial Pacific has been subparallel to the equator and to the equatorial zone of high biological productivity. An east-west profile of the equatorial sediment lens should thus resemble the diagram of Figure 7, although the precise relationship between time-stratigraphy and facies, and the thickness and nature of the deposits will depend on the latitude of the profile relative to the core and to the edges of the zone of high biological productivity.

Figure 8 is a stratigraphic profile across the northern part of the equatorial sediment lens through Sites DSDP 159 to DSDP 163. Between Sites DSDP 161 and DSDP 162 , the latitude of the profile shifts from south of the unnamed fracture zone between Clipperton and Clarion to north of it. In the eastern part of the profile, the sediment distribution and the attitude of the stratigraphic boundaries are similar to those of the model for a calcite compensation level between 4500 and 5000 meters. However, a zone of siliceous sediment comes in at the base of the sedimentary column in DSDP 161, and west and north of this site the entire sediment column is dominantly siliceous. Thus, factors other than those named above and modeled in Figure 7 must have operated on the sediments at least during the early Cenozoic. The late Cretaceous basal sediments of Site DSDP 163, on the other hand, are once again calcareous.

A parallel east-west section based on Leg 9 boreholes and located very near the axis of the equatorial sediment 


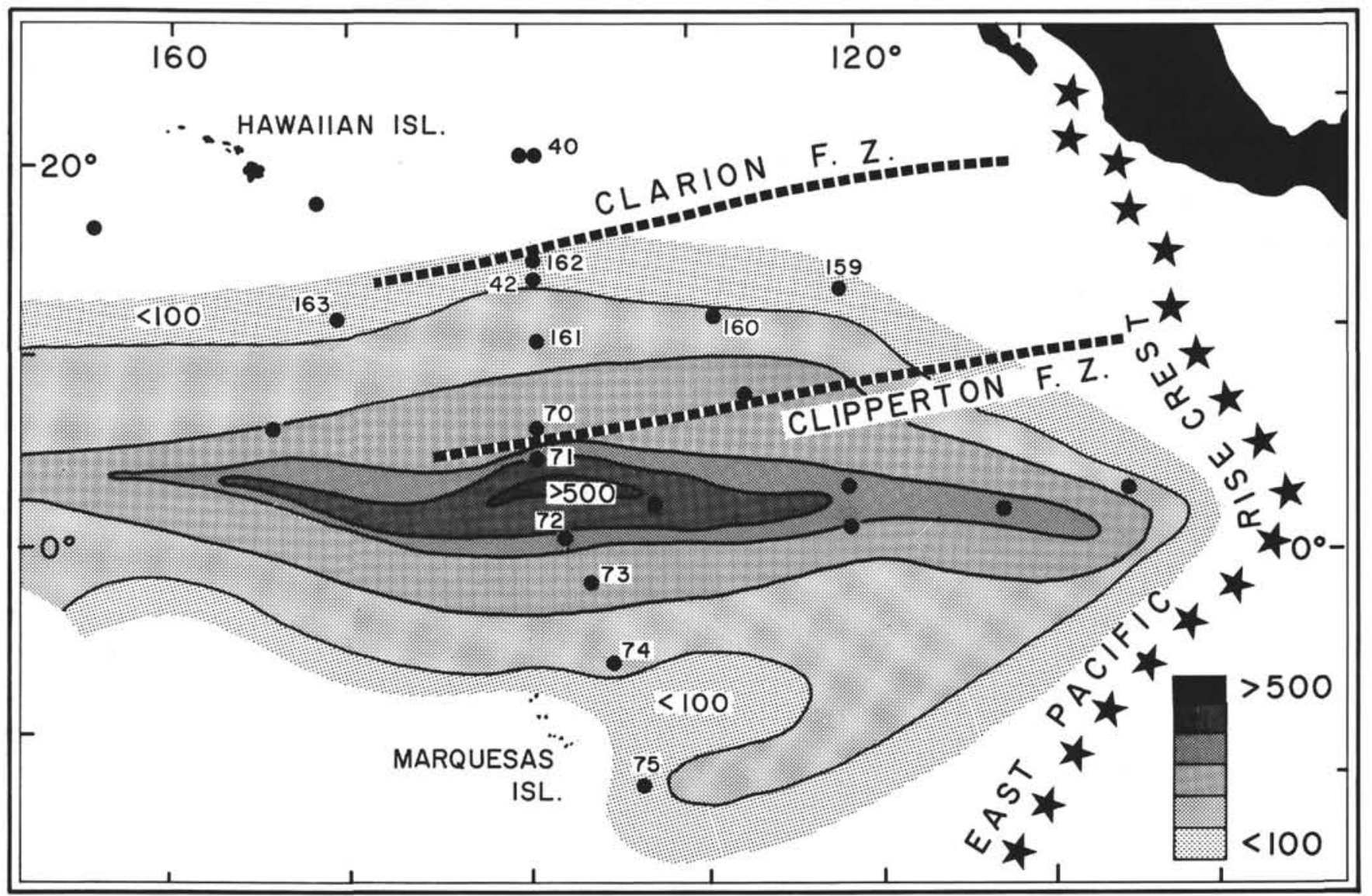

Figure 6. Isopach map of sediment thickness above basement (east of $130^{\circ} \mathrm{W}$ ) or above acoustically opaque Eocene cherts (west of $130^{\circ} \mathrm{W}$ ). Modified from Ewing et al. (1968). Sediment thickness in meters, assuming a velocity of $1.8 \mathrm{~km} / \mathrm{sec}$. Drill sites shown by black dots. Sites used in Figures 8, 9, and 10 of this paper are numbered.

lens is presented by Hays et al. (1972b). In the arrangement of sedimentary facies and in the attitudes of the stratigraphic boundaries this profile closely corresponds to the model of Figure 7, but it is more calcareous than the profile of Figure 8 because it lies closer to the core of the zone of high productivity.

Drilling results of Leg 8 (Tracey, Sutton et al., 1971b) and Leg 9 (Hays et al., 1972b) have shown that the effect of the equatorial zone of high biological productivity and the influence of the westward movement of the ocean floor and its corresponding increase in water depth are not adequate, by themselves, to explain the distribution of lithotypes in the equatorial Pacific. Changes in the width and accumulation rate of the equatorial zone of calcareous sediments, in the apparent depth of the calcite compensation level, and in the position of the zone of thickest sediments imply additional controlling factors.

The stratigraphic section across the equatorial zone of Figure 9, which is based on drill sites of Legs 5, 8, and 16, shows the expected lenticular shape of the sediment cover above basement. For each stratigraphic interval, the thickest section occurs approximately midway between the outcrop limits, and the sediments thin fairly symmetrically to the north and south. The regularity and symmetry are slightly marred where the profile crosses two and possibly three fracture zones, but since the probable offsets are on the order of a few hundred kilometers or less, the effects on sediment thickness and lithology are probably not great.

That additional factors control the deposition pattern becomes apparent when sediment thicknesses and gross lithologies are considered for a series of equal time intervals. In Figure 10 these properties are shown for ten successive 5 m.y. intervals from the Middle Eocene to the Quaternary. Sediment thicknesses were standardized to 50 per cent porosity in order to minimize variations due to differences in degree of consolidation. The interval boundaries are best estimates based on the time stratigraphy used in this volume and are ultimately based on interpolations within a time scale derived from rather sparse absolute age data. They are, at present, only approximations.

The upper two intervals, although somewhat truncated by sea floor erosion at the northern end, show a symmetrical development with a thick central calcareous wedge changing southward and northward to thin siliceous deposits. They correspond closely to the distribution expected from prevailing depositional conditions. For the 10-15 m.y. interval, the symmetry is less clear, but this may well be due to erosion of the thin siliceous sediments at the northern end. The maximum thickness of this interval and, 


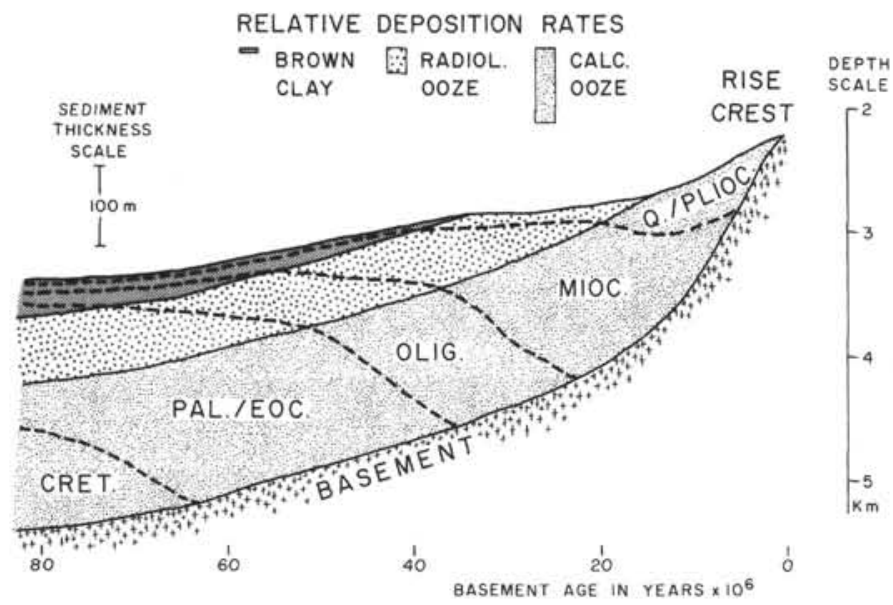

Figure 7. Model of lithologic units (simplified) and stratigraphic boundaries in the sediment cover of a spreading ridge in the equatorial Pacific. Horizontal scale in millions of years. Sediment thicknesses of individual units have been computed on the basis of ratios between accumulation rates shown at top. Note that water depth scale at right refers to depth of basement, while sediment scale at left refers to sediment thickness. Sea floor as shown is, therefore, not to water depth scale. Note downslope and upward change in lithology and convergence of time boundaries towards upper left so that with increasing age, the likelihood of erosional removal of deposits representing long time intervals increases. therefore, its aggregate accumulation rate are nearly twice those of the overlying intervals. Although this may be a real increase, it may also be an artifact produced by errors in assigning absolute ages to biostratigraphic boundaries within the Miocene. Moore (1972) has shown that the assignment of absolute ages to these boundaries is still very uncertain and that during the last four years assigned ages have varied by several million years. What is not an artifact, however, is the overall decrease in aggregate accumulation rate from the Oligocene to the late Cenozoic. Even though the precise change from interval to interval may be clouded by uncertainties regarding the age of the interval boundaries, the trend is clear. In addition, the general and pronounced decrease in the width of the zone of calcareous deposition which took place during the same interval is also real. During the Oligocene and lower Miocene, the calcareous deposits span nearly 30 degrees of latitude. The width of this zone began to decrease early in the Miocene and the middle Miocene zone is about 15 degrees wide. The present width is less than 10 degrees. The onset of the reduction appears to have been rather abrupt between 15 and $20 \mathrm{~m} . y$. ago. For the period of greatest width, no associated fringing siliceous deposits have been recovered; they may exist farther north and south or they may have been removed by erosion.

Erosional disconformities are difficult to recognize in DSDP cores, but since siliceous deposits are absent from the south margin of the Oligocene calcareous zone as well as from the more commonly eroded northern edge, it seems

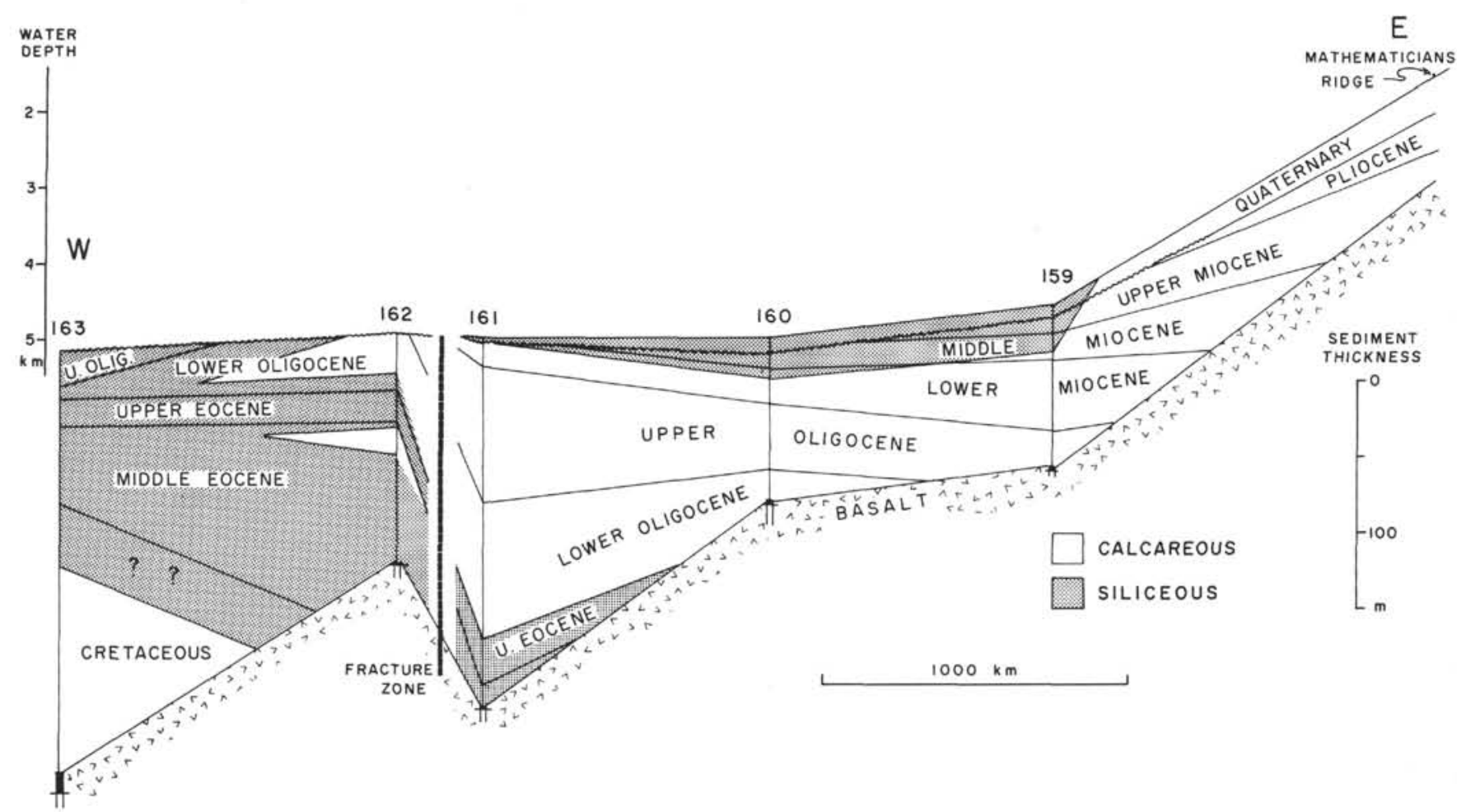

Figure 8. Lithologic units and stratigraphic boundaries in an east-west profile through the drill sites of Leg 16. Note the northward jump of the profile across an unnamed fracture zone between sites DSDP 161 and DSDP 162. Water depth scale on upper left; sediment thickness scale on lower right. Horizontal scale approximate. Wavy lines represent erosional disconformities. No correction for variations in degree of consolidation. Sediment thickness at crest of Mathematicians Ridge from Glomar Challenger reflection profiles. Age of oldest sediment there inferred from Figure 3. 
$\mathrm{N}$

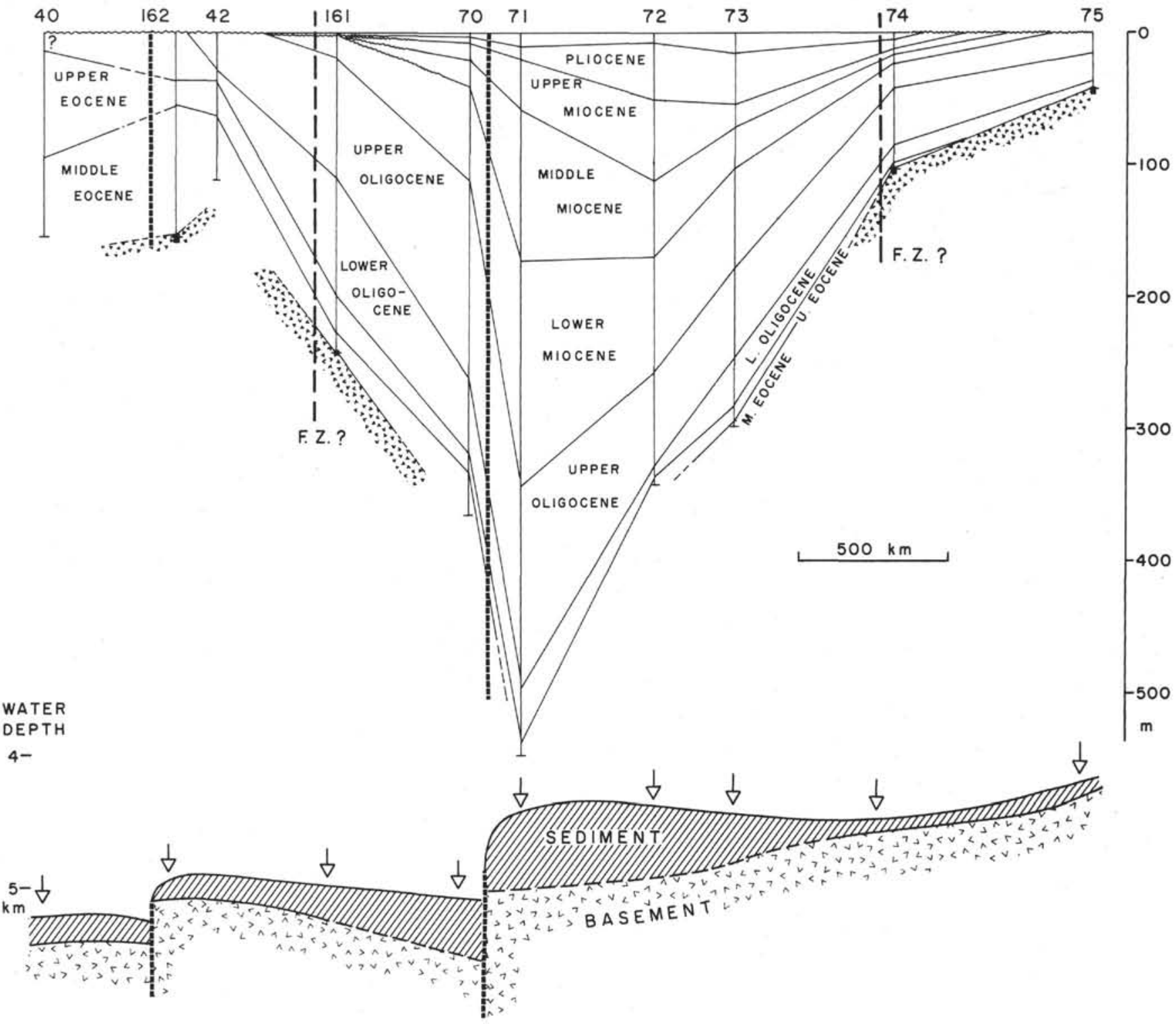

Figure 9. Stratigraphic profile across the equator at approximately $140^{\circ} \mathrm{W}$, based on holes of Legs 5, 8, and 16. Top: stratigraphic section; vertical scale in meters at right. Bottom: sea floor topographic and sediment thickness (vertical scale at left): fracture zone between Clarion and Clipperton not shown because of its apparent small topographic effect. Locations on Figure 5.

that the pattern of Figure 10 may reflect primary, rather than modified depositional patterns in the Oligocene.

Both the width of calcareous deposits and their accumulation rates were greatest during the upper Oligocene. The sedimentation rate was nearly four times its Pliocene-Quaternary value during this interval. A slower sedimentation rate and a narrower zone of calcareous sediment are evident during the 30-35 m.y. interval, but, even so, the width and accumulation rate were significantly greater than they are at present.

The Eocene-Oligocene boundary makes a sharp lithological break. Eocene accumulation rates were low, on the order of one-half of the rate for the most recent 5 m.y., and one-fourth or less of the Oligocene rate, and calcareous sediments, even in the center of the zone of deposition, are thin and of limited latitudinal extent. Moreover, the calcerous sediment that is present is not the massive nannofossil chalk ooze that characterizes the Oligocene and Miocene but occurs as interbedded radiolarian-nannofossil oozes and radiolarian oozes of wholly different character. This regime persists from the latest Cretaceous through the entire lower Cenozoic and is accompanied by a slight decrease in accumulation rate from 50 to 35 million years B. P.

The distribution of biogenous sediments suggests that the equatorial zone of high biological productivity was widest and perhaps most productive during the Oligocene and early Miocene and has steadily contracted and become 


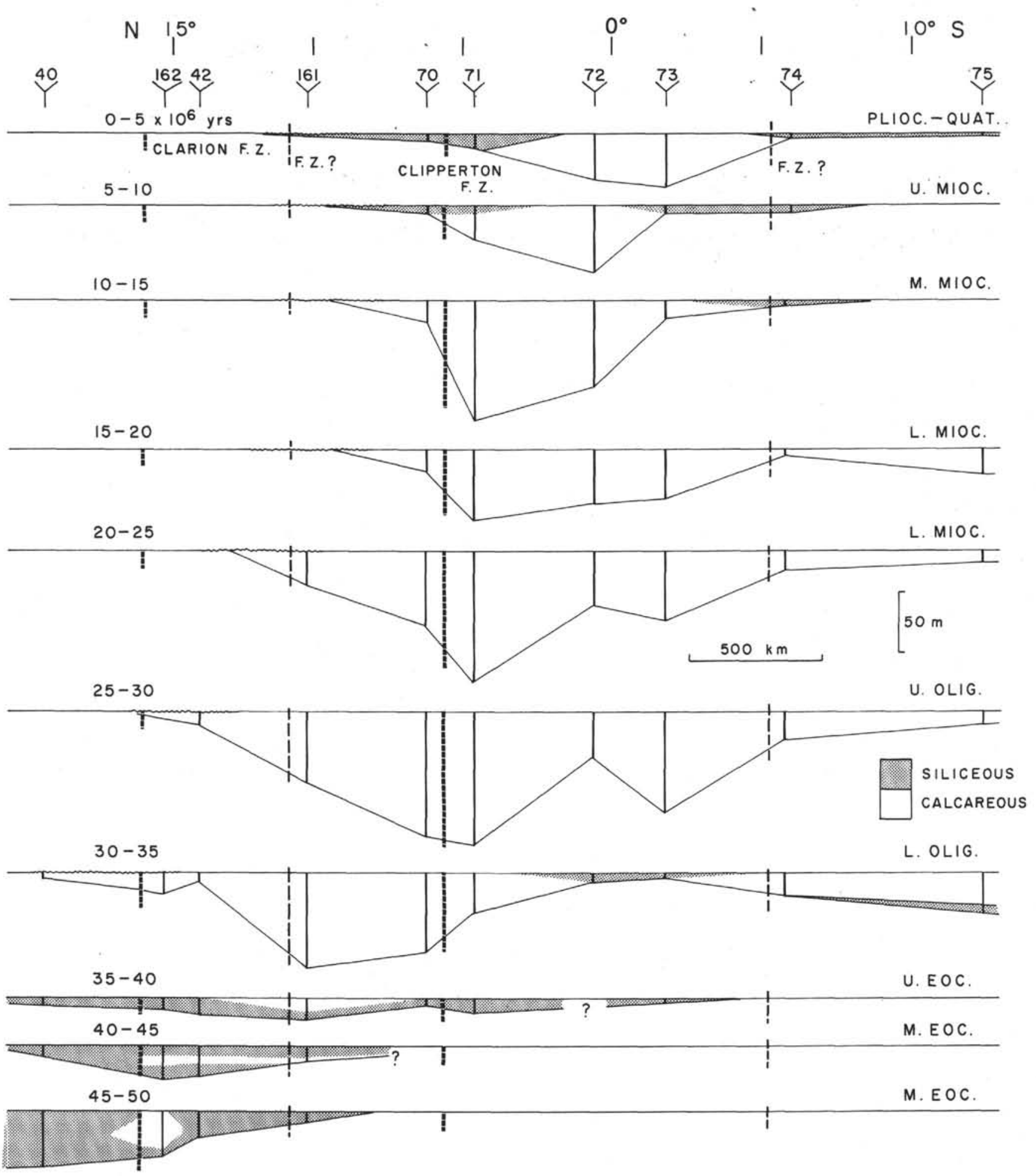

Figure 10. Thicknesses and general lithology of sediments on the $140^{\circ} \mathrm{W}$ traverse (Figure 9) for ten 5-m. $y$. intervals from the Quaternary to the middle Eocene. Stratigraphic names at right are approximate. Intervals are from Leg 16 time stratigraphic table. Heavy dashed lines are positions of Clarion and Clipperton fracture zones; light dashed lines denote unnamed fracture zones of uncertain position shown on Figure 2. Wavy lines mark probable erosional disconformities. Sediment thicknesses standardized to 50 per cent porosity. 
less productive from the middle Miocene to the present. Unfortunately, the same pattern can be produced by holding productivity constant and changing the rate of dissolution. Thus, in Figure 10, the 20-25 m.y. (lower Miocene) section can be converted to the 5-10 m.y. section simply by increasing the calcite dissolution rate by 8 $\mathrm{mm} / 10^{3} \mathrm{y}$. In addition, large changes, either in productivity or in rate of deep-water dissolution of calcite took place at the end of the Cretaceous and again at the end of the Eocene, leading to an intervening almost totally siliceous interval. Present knowledge suggests that the best explanation for these changes is a shoaling of the calcite compensation level at the end of the Cretaceous and a deepening at the end of the Eocene. Another period of more gradual shoaling may be invoked to explain, at least in part, the changes occurring since the middle Miocene (Heath, 1969) but, as discussed above, cannot be distinguished from productivity changes on the basis of our data alone. The possible reasons for these fluctuations in the calcite compensation level are unclear but may be related to shifting loci of formation of bottom waters on a global scale. Because changes in the calcite compensation level and in the width and intensity of the equatorial zone of high biological productivity are superimposed on changes in elevation, latitude, and longitude of the ocean floor induced by sea floor spreading and movements of the Pacific plate as a whole, the problem is complex and even a semiquantitative evaluation is impossible without more precise analytical data and some numerical modeling of the system.

\section{Northward Migration of the Pacific Plate}

The sections of Figure 10 show that the axis of thickest sediment lies progressively farther north for successively older sediments. Although the wide spacing of control points and the uncertainties of the interval boundaries preclude a very precise determination of the point of maximum thickness for each interval, a general temporal trend can be established with reasonable confidence (Figure 11). The shift from a point near $20^{\circ} \mathrm{N}$ in the $45-50$ m.y. interval to one slightly south of the equator for the present time is systematic and unambiguous. The trend may be slightly distorted because the traverse crosses several fracture zones, but in view of the generally small offsets on these fracture zones such distortion is probably minor.

It is improbable that the zone of high biological productivity has shifted southward with time because its presence is a function of the planetary wind system. Hence, the distribution of Cenozoic sediments must reflect a northward shift of the Pacific lithospheric plate. Francheteau et al. (1970) have documented such a shift, which has been postulated by numerous authors, by means of magnetically determined paleolatitudes of seamount clusters. The trend derived from their observations is similar to the shift of the axis of maximum sedimentation (Figure 11). It must be remembered that the data which form the basis of Figure 11 allow only a determination of the northward component of plate movement and do not preclude a mean movement in another direction. Although conclusions as to the absolute plate motion based only on a north-south profile must be somewhat speculative, it

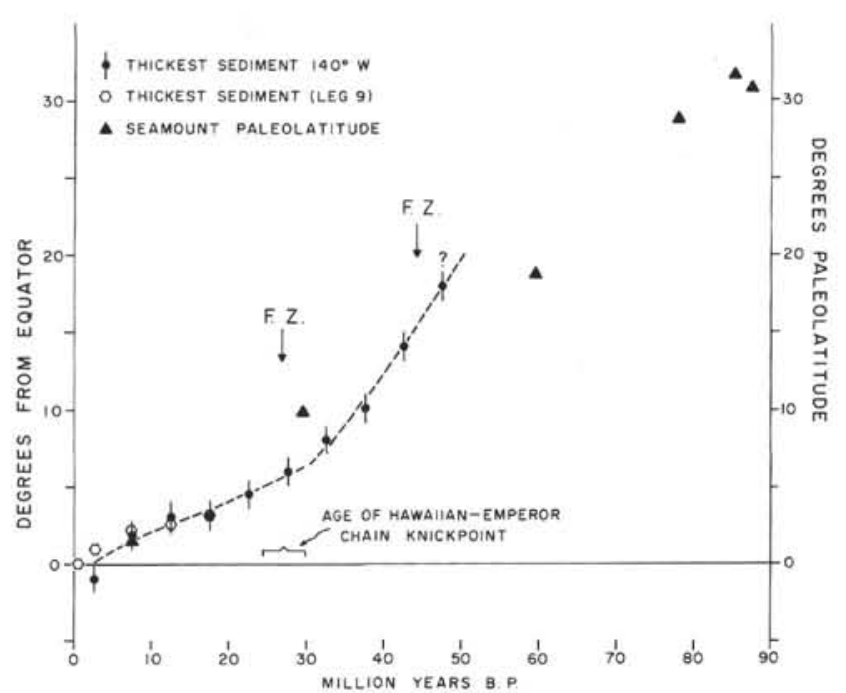

Figure 11. Latitudes of thickest sediment accumulation for each 5-m. y. interval of Figure 10 plotted against age. Error bars indicate reasonable estimates of the latitude uncertainty but do not take into account uncertainties in the time scale used. Arrows marked F.Z. show positions of the most important fracture zones. Open hexagons mark the positions of the thickest sediment for $\propto$ short north-south traverse near $125^{\circ}-120^{\circ} \mathrm{W}$ lafter Hays et al., 1972b). Triangles are approximate age-paleolatitude positions of seamounts analyzed by Francheteau et al. (1971).

appears that the northward component of movement of the sediment axis was about twice as fast between 30 and 50 m.y. ago as it has been subsequently. Morgan $(1971,1972)$ has proposed that the absolute motion of the Pacific plate has been recorded by volcanic chains formed over fixed mantle hot spots and that the trends and age relations of several Pacific volcanic lineaments, such as the Line Islands and the Hawaiian-Emperor seamount chain, preserve this record. Thus, the bend at the junction of the Hawaiian and Emperor seamount chains represents a change in the direction of drift of the Pacific plate from almost directly north to a more westerly direction. Jackson et al. (1972) have estimated that this change in direction of motion occurred between 25 and 30 m.y. ago. The correspondence between this interval and the rate change of Figure 11 suggests that the change in the rate of northward migration of the sedimentation axis resulted from a change in direction rather than rate of motion of the Pacific plate.

Hays et al. (1972b), on the basis of Leg 9 drill sites spanning a narrow latitudinal range, have argued that they see no evidence for a northward migration of the axis of sedimentation. Their points have been replotted on Figure 11 ; it is clear that they conform to the general trend within the rather wide limits of precision of the data, and that the Leg 9 data are inadequate to support or refute the negative conclusion reached by Hays et al.

For the past 50 m.y. the gross trends in thickness and facies distribution of central and eastern equatorial Pacific sediments deposited seem fairly well established. The earlier record, particularly the portion from the basal Maestrichtian to the middle Eocene, is still quite enigmatic. 
Additional drill sites north of the existing array and perhaps covering areas such as the Hess Rise would seem most likely to resolve this enigma.

\section{REFERENCES}

Anderson, R. N. and Davis, E. E., 1972. A topographic interpretation of the Clipperton Ridge, Mathematicians Ridge, East Pacific Rise System. EOS. 53, 414.

Bader, R. G., Gerard, R. D. et al., 1970. Initial Reports of the Deep Sea Drilling Project, Volume IV. Washington (U.S. Government Printing Office). 735 p.

Berger, W. H., 1971. Sedimentation of planktonic foraminifera. Marine Geol. 11, 325.

Berggren, W. A., 1969. Cenozoic chronostratigraphy, planktonic foraminiferal zonation and the radiometric time scale. Nature, 224, 1072.

Bramlette, M. N., 1961. Pelagic sediments. In Oceanography, M. Sears (Ed.), Am. Assoc. Adv. Sci., Washington, D. C. 345 .

Chase, T. E., Menard, H. W. and J. Mammerickx, 1970. Bathymetry of the North Pacific. Scripps Inst. Oceanog., Univ. Calif., La Jolla, Càlif.

Ewing, J. I., Ewing, M., Aitken, T. and Ludwig, W. J., 1968. North Pacific sediment layers measured by seismic profiling. In The Crust and Upper Mantle of the Pacific Area, L. Knopoff (Ed.), Am. Geophys. Union Monograph 12, 147.

Francheteau, J., Harrison, C. G. A., Sclater, J. G. and Richards, M. L., 1970. Magnetization of Pacific seamounts: a preliminary polar curve for the northeastern Pacific. J. Geophys. Res. 15, 2035.

Hayes, D. E. and Pitman, W. C., 1970. Magnetic lineations in the north Pacific. In Geological Investigations of the North Pacific, J. D. Hays (Ed.), Geol. Soc. Am. Mem. 126, 291.

Hays, J. D. et al., 1972a. Initial Reports of the Deep Sea Drilling Project, Volume IX. Washington (U.S. Government Printing Office), 1205 p. 1972b. An interpretation of the geologic history of the eastern equatorial Pacific from the drilling results of Glomar Challenger, Leg 9. In Hays, et al., 1972. Initial Reports of the Deep Sea Drilling Project, Volume IX, Washington (U.S. Government Printing Office). 909.

Heath, G. R., 1969. Carbonate sedimentation in the abyssal equatorial Pacific during the past 50 million years. Bull. Geol. Soc. Am. 80, 689.

Heath, G. R. and Culberson, C. 1970. Calcite: degree of saturation, rate of dissolution and the compensation depth in the deep oceans. Bull. Geol. Soc. Am. 81, 3157.
Heirtzler, J. R., Dickson, G. O., Herron, E. M., Pitman, W. C. and LePichon, X., 1968. Marine magnetic anomalies, geomagnetic field reversals and motions of the ocean floor and continents. J. Geophys. Res. 73, 2119.

Herron, E.M., 1972. Sea-floor spreading and the Cenozoic history of the East Central Pacific. Bull. Geol. Soc. Am. 83,1671 .

Jackson, E. D., Silver, E. A. and Dalrymple, G. B., 1972. Hawaiian-Emperor chain and its relation to circumpacific tectonics. Bull. Geol. Soc. Am. 83, 601.

LePichon, X., 1968. Seafloor spreading and continental drift. J. Geophys. Res. 73, 3661.

MacDougall, D., 1971. Deep Sea Drilling: age and composition of an Atlantic basaltic intrusion. Science. 171,1244 .

McKenzie, D. P. and Sclater, J. G., 1969. Heat flow in the eastern Pacific and sea floor spreading. Bull. Volcanol. 33, 101.

McManus, D. A., Burns, R. E. et al., 1970. Initial Reports of the Deep Sea Drilling Project, Volume V. Washington (U.S. Government Printing Office), 827 p.

Meyerhoff, A. A. and Meyerhoff, H. A., 1972a. The new global tectonics: major inconsistencies. Bull. Am. Assoc. Petrol. Geologists, 56, 269.

1972b. The new global tectonics: age of linear magnetic anomalies of the ocean basins. Bull. Am. Assoc. Petrol. Geologists. 56, 337.

Moore, T.C., Jr., 1972. DSDP: successes, failures, proposals. Geotimes, 17, 27.

Morgan, W. J., 1968. Rises, trenches, great faults, and crustal blocks. J. Geophys. Res. 73, 1959. 1971. Convection plumes in the lower mantle. Nature, 230, 42. 1972. Deep mantle convection plumes and plate motions. Bull. Am. Assoc. Petrol. Geologists. 56, 203.

Sclater, J. G., Anderson, R. N. and Bell, M. L., 1971. Elevation of ridges and evolution of the central eastern Pacific. J. Geophys. Res. 76, 7888.

Tracey, J. I., Jr., Sutton, G. H. et al., 1971a. Initial Reports of the Deep Sea Drilling Project, Volume VIII. Washington (U.S. Government Printing Office), 1037 p. 1971b. Leg VIII summary. In Tracey, J. I., Jr., Sutton, G. H. et al., 1971. Initial Reports of the Deep Sea Drilling Project, Volume VIII, Washington (U.S. Government Printing Office), 17.

Van Andel, Tj. H., 1972. Establishing the age of the oceanic crust. Comments Earth Sci.: Geophys. 2, 6.

Van Andel, Tj. H. and Komar, P. D., 1969. Ponded sediments of the Mid-Atlantic Ridge between $22^{\circ}$ and $23^{\circ}$ north latitude. Bull. Geol. Soc. Am. 80, 1187.

Winterer, E. L., Et al., 1971. Deep Sea Drilling Project Leg 17. Geotimes, 16, 12 . 